\title{
Biofuel Resources Plan: Theoretical Case Assessment of Automotive Industries
}

\author{
Luke O. Ajuka ${ }^{1}$, Olawole A. Kuti ${ }^{2}$, Fadare D.A. ${ }^{3}$ \\ ${ }^{1}$ Automotive Engineering Department, University of Ibadan, Nigeria \\ ${ }^{2}$ Mechanical Engineering Department, Manchester Metropolitan University, UK \\ ${ }^{3}$ Mechanical Engineering Department, University of Ibadan, Nigeria
}

\begin{abstract}
Crude oil exhaustion and greenhouse emissions have remained a global concern till date. Domestic production of biofuel blends and micro-emulsion as substitutes for conventional fuel in tackling greenhouse gas emission has challenges like feedstock inadequacy, fuel-energy content, compatibility, oxidation stability and other automotive fuel property issues. Strategies to address these issues are discussed in this study. Case study of Nigeria shows that an annual conversion rate of $6.9 / 3.3 \%$ (2.1: 1) of cassava wastes will meet its E10/E5 blend from local production capacity. An effort has been made to correlate existing ethanol and biodiesel yields, $\mathcal{E} \psi_{\mathrm{E}}$ and $\varepsilon \psi_{\mathrm{B}}$ with expected oil yield as a function of gasoline and diesel shares, $\alpha_{\mathrm{E}}$ and $\alpha_{\mathrm{B}}$ per hectare of cultivation, to generate total oil yield per desired short and medium term biofuel targets utilizing selected feedstock at applicable yield bounds. A typical E10 gasohol from cassava will need 16,133 and 28,543 hectares from cassava plantation to meet its annual short and medium term biofuel targets. The $\mathrm{r}^{2}$-square value of 0.6402 for $\mathrm{CF} / \mathrm{S}_{\text {Peel }}$ and 0.9044 for $\mathrm{CF} / \mathrm{S}_{\text {Pulp }}$ is an indication that more litre/tonne volume of ethanol could be produced from $\mathrm{CF} / \mathrm{S}_{\text {Peel }}$ except for in consistency when ammonia extract and urea are used as nitrogen source. Specific energy for direct ethanol fuel cell (DEFC) from daily production capacity equivalence of E10 per annum is estimated at $2.34 \mathrm{GWh} / \mathrm{Kg}$. Biofuel and fuel cells are good alternatives to explore as replacement of fossil fuel in automotive application.
\end{abstract}

KEYWORDS: Automotive fuel; greenhouse gas; feedstock; wastes; micro-emulsion; biofuel; fuel cell.

\section{NOMENCLATURE}

$\mathrm{r}^{2}$-squared - Coefficient of determination

$\mathrm{C}_{\mathrm{F}} / \mathrm{S}_{\mathrm{Peel}}$ - Cassava flour/starch Pulp

$\mathrm{C}_{\mathrm{F}} / \mathrm{S}_{\mathrm{Pulp}}$ - Cassava flour/starch Pulp

$\mathrm{E}_{\mathrm{XX}}-\%$ of ethanol in bioethanol blend

$\mathrm{B}_{\mathrm{XX}}-\%$ of biodiesel in biodiesel blend

ASTM - American Society for Testing and Materials

ES - European standard

Ha - Hectares

RU - Rubber seed upper yield

RL - Rubber seed lower yield

Lit - Litre

GHG - Greenhouse gas

\section{INTRODUCTION}

The global automobiles count has increased exponentially, trending with utilization of battery electric vehicles, synthetic fuel and fuel cell in the recent times, accounting for significance of the transportation sector in global economies. Developing economies account for about $10 \%$ of the worldwide automobile population and a little over $20 \%$ of the transport energy consumption [1]. Demands for Motor vehicles have contributed to hazardous emissions such as oxides of carbon $\left(\mathrm{CO}_{2}\right),(\mathrm{CO})$ and oxides of nitrogen
$\left(\mathrm{NO}_{\mathrm{x}}\right)$, making it a contributor to air pollution in urban environments [2]. Quality air examination by environmentalists on automobile pollution rate is therefore essential [3].

Dependence on fossil fuel over time may not be sustained given the swift increase ofpopulation, energy utilization andco-development activities in science, technology and socio-economic [4], wherein the recent proven reserves of some countries are exhaustive. Environmental challenges associated with fossil fuel burning is a major cause of greenhouse gas which causes changes in climate, drought emergence, spread of diseases and uneven distribution in population sizes of both plant and animals $[5,6]$. Within the last quarter of a century, about seventy-five percent $(75 \%)$ man-made $\mathrm{CO}_{2}$ emissions results from burning fossil fuels [6].

Oil crisis have prompted biofuels as alternatives to fossil fuel by combating the adverse effects of carbon deposits and engine injector coking. The use of biodiesel in automobiles has attracted substantive prominence with the aim of improving the viscosity of conventional fuels by blending or diluting with certain percentage of biofuel. Caterpillar Brazil utilised 10\% (E10) dope of vegetable oil in diesel to ensure total engine power maintenance without adjustment or Luke O. Ajuka ${ }^{1}$, ETJ Volume 6 Issue 08 August 2021 
modification [7]. Biofuel production is from dual feedstock (see Figure 1); first and second generation biofuels. Production of biofuel from vegetable oils and fats from advanced feedstock are by a chemical process named transesterification, a process by which a caustic soda catalyst, methanol (alcohol) is reacted with oil or fat, producing an ester and glycerol. This process helps to remove the glycerin, the secondary product of biodiesel production [8; 9]. More so, the conventional conversion systems of extracting the sugar in sugarcane, and starch in cassava feedstock consist of microbial breakdown (yeast, hydrolysis and saccharification, respectively) to ethanol through fermentation. For example, tropical feedstock for biofuels in automotive applications is shown in Figure 2. This is already a directional gap in fuel science, which Automotive Institutions should explore for emission substitution and better specific energy content.

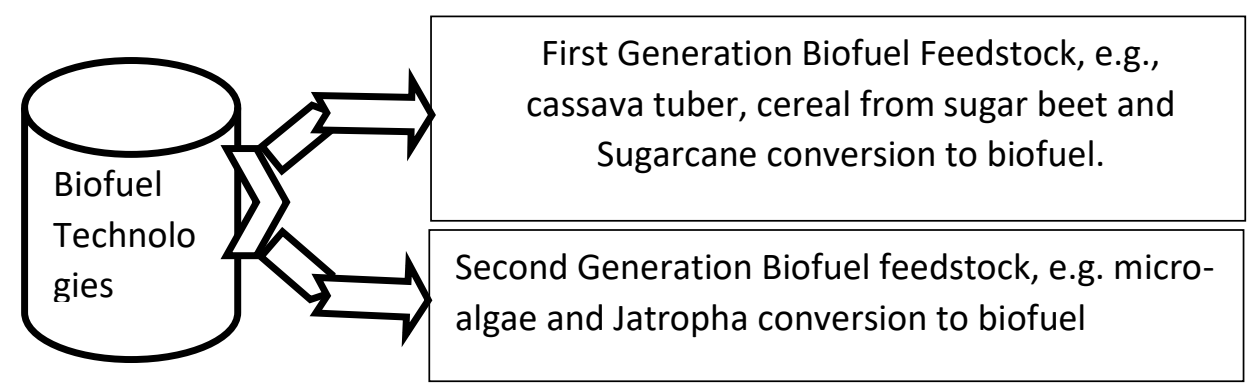

Figure 1: Biofuel Technologies [10]

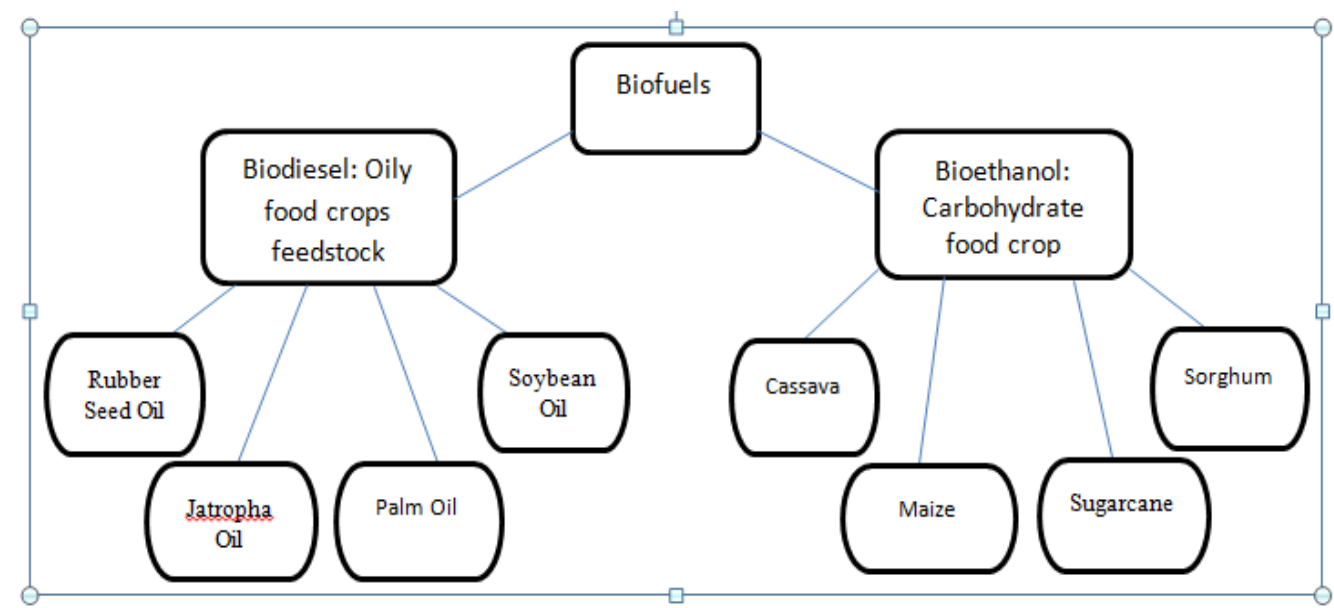

Figure 2: Some potential sources of biofuels for Automobile application[11].

\section{Local Demands and Economic Status Of Biofuel}

Global energy demand across the world is an outcome of economic development at all levels from industrialization and modernization. As at 2008, only 7 states in the United Statesare yet to have E85 fuel in market to the public [12; 13]. It was reported that total biofuel consumption per day in the USA is 1.09 million barrels per day [14]. Nigeria's import from 2005 to 2007 was $112.04,22.28$ to 114.89 million litres of ethanol, and still imports till date [15]. It's national biofuel policy target of $100 \%$ by 2020 as reported by Ohimain in 2012 [16] which projects that a $10 \%$ gasoline substitution demand for ethanol is 2.0 billion litre per annum while the $20 \%$ diesel substitution demand for biodiesel is 900 million litres, respectively in 2020 , and are yet to be met. Annual energy demand rate of United State and Nigeria are $36.2 \%$ and $20.2 \%$, and energy security remains a key issue when external factors influences the economic terms of any country. The demand for biofuels is much larger than those of chemicals in the market[17]. Biodiesel is a good lubricant, and is reported to be better than petro-diesel by $66 \%$ [18]. Typical case of Nigeria and United States' biofuel targets and gradual preparation towards the exhaustion of its reserve (Table 1).

Table 1: Biofuel targets of some selected countries

\begin{tabular}{|l|l|l|l|l|}
\hline S/N & Type of Biofuels & $0-5$ yrs (Short Term) & $10-15$ yrs (Medium Term) & $>15 y r s($ Long Term) \\
\hline $\mathbf{1}$ & $\begin{array}{l}\text { Bioethanol (Target as share of } \\
\text { gasoline consumption, \%) }\end{array}$ & $52.5 \%$ & $\mathrm{n} / \mathrm{a}$ \\
\hline $\mathbf{2}$ & $\begin{array}{l}\text { Biodiesel (Target as share of } \\
\text { diesel/fuel oil consumption, \%) }\end{array}$ & $18.2 \%$ & $\mathrm{n} / \mathrm{a}$ & \\
\hline 986 &
\end{tabular}


"Biofuel Resources Plan: Theoretical Case Assessment of Automotive Industries"

\begin{tabular}{|c|c|c|c|c|}
\hline 3 & $\begin{array}{l}\text { United State Biofuel on Corn crop } \\
\text { yield, total crop yields (Target as } \\
\text { share of finished motor fuel: } \\
\text { gasoline, distillate and jet, } \% \text { ) }\end{array}$ & $\left.\begin{array}{lll}25 \% & (2007 & -2012\end{array}\right)$, & $\mathrm{n} / \mathrm{a}, 8.8 \%$ & $\mathrm{n} / \mathrm{a}, 55 \%$ \\
\hline
\end{tabular}

Source: $[16 ; 17 ; 19]$

\section{Biofuel Potential (Nigeria as Case Study)}

Oil export from a country like Nigeria between 2009 and 2013 was averaged 2.4million barrels per day (b/d) of oil, and $2.44 \mathrm{~b} / \mathrm{d}$ in 2005 but has plummeted to about 1.9 million $\mathrm{b} / \mathrm{d}$ in 2015 [20]. Based on 7\% projected growth rate, sector energy demand is expected to rise to 112.67 and 224.54 mtoe in 2020 and 2030 [21], considering the current estimate of 37 billion barrels from oil reserve in its daily production capacity of about 2.5 million barrels of crude oil. This implies that at the current rate of utilization, the oil will be depleted in 32 years from now [22].Over-reliance on petro-fuel is being addressed by adopting locally available biofuels cultivated from feedstock for energy security. Expected minimal green-house gas (GHG) emission, better fuel characteristics for vehicles, employment rise can be sustained through a national biofuel policy and inducements. This bioenergy resource can be fully optimized from blending of biofuel with conventional petro-fuel to relatively high performing stand-alone agricultural feedstock. Jatropha plant is bountifully used for non-oil production purposes like fencing land boundaries in the eastern region of Nigeria and a handful of plantations have been established in the Northern Nigeria as pilot studies to check desertification [23].

Nigeria has about 20 bioethanol projects, with another 13 coming up, earning the projects a pioneer status grants since their production facilities run on domestically sourced feedstock in the production of fuel ethanol and/or power cogeneration [24]. This pioneer bioethanol project implementation policy includes the Nigerian National Petroleum Corporation (NNPC), Global Biofuel Limited (locations at Edo, Kogi, Osun, Ondo, Kwara, Niger, Kaduna, Ekiti, Oyo, and Plateau states), Ethanig Nigeria Limited, Savannah Sugarcane Factory (a subsidiary of Dangote Industries Ltd), KwaraCasplex Limited, Ekiti, Ondo, and some other state governments. Among the twenty (20) pioneer projects, ten (10) bio-refineries were designed to use cassava feedstock, eight (8) used sugarcane while other remaining two (2) are intended to use sorghum.

The biofuel feedstock detail includes sugarcane in Kupto, Gombe state, Buruku and Agasha, Benue state; cassava in Okeluse and Ebenebe(Ondo state andAnambra state) and oil palm in Cross-River state. Its projected mechanized plan is to have farm landmasses for 200,000 hectares (ha) of sugarcane; 150,000 ha of cassava; 125,000 ha of oil palm and 125,000 ha of jatropha[24], respectively. Automotive biofuel (ABF) project by NNPC on electricity generation from sugarcane feedstock through bioethanol production from its various dispersed projects per year is estimated at 345 million litres, to generate $187-192 \mathrm{MW}$ of electricity from an estimated 74,374 hectares of land cultivation, Ethanig-Starcrest ethanol production from sugarcane is estimated at 200 million litres for electricity generation from 100,000 ha of cultivated land while Dangote Industries (savannah sugar company) ethanol production from sugarcane is 1 million litres (and includes 1 billion tonnes of Sugar, 100, 000 tonnes fertilizer and 300MW electricity) from estimated 96,000 hectares of land cultivation, respectively. The cassava ethanol production by NNPC, Kwara Casplex limited (kwara state), Ekiti state, Taraba, Niger state, Ogun state from cassava are 80-120, $38.86,103.1,72,27$ and 3 million litres from 30,000; 15,$000 ; 27,500 ; 30,000 ; 15,000$ and 5,000 hectares of land cultivated [24], respectively. The projection by Global biofuels Limited (Nigeria) from bio-refining of sweet sorghum is estimated at about 114.8 million litres on 41,000 hectares of land cultivation [24].These would yield several tons of oil seeds annually per hectare. Meanwhile, this specific phase is expected to aid a swift growth, self-thriving and market-driven production of biodiesel in the Nigeria.

Many researchers have pointed at the biofuel potentials in terms of biofuel substitutes and strategic policies to meet energy demand, however, none of them have itemized steps to estimate the biofuel-energy mix to meet targeted proposition and extended energy demands. Since feasibility has been established through existing plantation coverage, nurseries development, seed collections and oil extraction, trans-esterification, blending and domestic marketing are already in existence, this paper presents a forecast of feedstock-fuel target, from waste and agricultural feedstock to meet automotive energy target. The prime objectives of this paper are:

1. to review the energy situation, potentials of biofuel resource (BFR) and blends as alternatives to conventional fuels.

2. to estimate the expected waste, land usage and specific energy for fuel cells using Nigeria as a case study. 


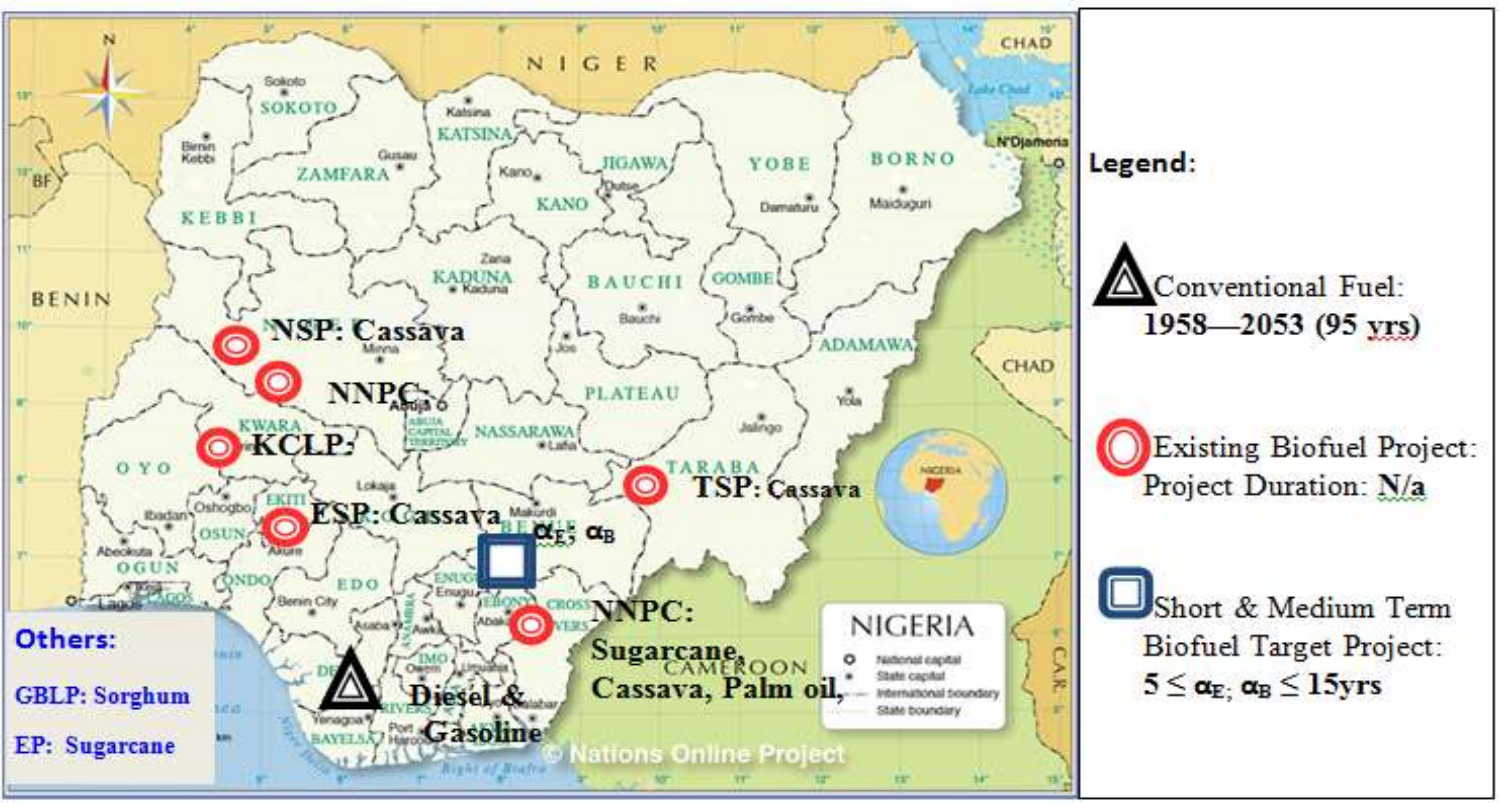

Figure 3: Nigeria Automotive Fuel Distribution: Emerging [22] and Future Target;

NNPC: Nigerian National Petroleum Commission; KCL: KwaraCaplex Limited; ESP: Ekiti State Project; TSP: Taraba State Project; NSP: Niger State Project; GBLP: Global Biofuels Limited Project.

\section{MICRO-EMULSION AND BIOFUEL BLENDS}

Heating, trans-esterification, and micro-emulsification are diesel substitute making methods. The widest commercial application of diesel fuel blends is through transesterification, although, hybrid fuels from microemulsification were reported as been more suitable substitute for diesel fuel [25;26]. Conversion of vegetable oil, animal fats and feedstock to biodiesel and bioethanol depends on feedstock characteristics (Table 2), i.e. jatropha oil from jatropha seeds involves two simple mechanical operations and palm kernel oil from palm kernel takes only a two-in-one mechanical process in the local production of the oil $[27 ; 28 ; 29]$, as shown in Figure 3. But, it is reported that the spray atomization by the fuel injectors into the combustion chamber is characterized by viscous and peculiar chemical properties, and choking may set in as the oil is 11 to 17 times thicker than conventional diesel fuel, the high viscosity can be reduced by alcoholysis[30]. These ways the synthesized fuel properties are made more similar to the conventional fuel types (biodiesel and ethanol/ diesel and gasoline).

Micro-emulsions are described as clear, stable isotropic fluid of equilibrium colloidal dispersion ranging from 1-150 nm formed by spontaneous blend of two commonly immiscible liquids with one or more ionic amphiphiles[31], i.e. oil and aqueous phase as well as a surfactant. Direct or diluted blends may not require a surfactant but they still reduce associated viscous characteristic and engine performance issues like injector coking and the carbon deposits creation. Jain and Sharma reported that existing micro-emulsions from alcohols (e.g.,butanol, hexanol and octanol) meet the intense viscosity limit of diesel engines [32].

Table 2: Property Comparison of Common Fuel Types in Nigeria.

\begin{tabular}{|c|c|c|c|c|c|c|c|c|c|}
\hline $\mathbf{S} / \mathbf{N}$ & $\begin{array}{l}\text { Vegetable Oil } \\
\text { types }\end{array}$ & $\mathbf{C N}$ & $\begin{array}{l}\text { HV } \\
(\mathbf{k J} / \mathbf{k g})\end{array}$ & $\begin{array}{l}\text { Viscosity } \\
\left(\mathrm{mm}^{2} / \mathrm{s},\right. \\
\text { Temp) }\end{array}$ & $\begin{array}{l}\text { Cloud } \\
\text { Point } \\
\left({ }^{\circ} \mathbf{C}\right)\end{array}$ & $\begin{array}{l}\text { Pour } \\
\text { Point } \\
\left({ }^{\circ} \mathrm{C}\right)\end{array}$ & $\begin{array}{l}\text { Flash } \\
\text { Point } \\
\left({ }^{\circ} \mathrm{C}\right)\end{array}$ & $\begin{array}{l}\text { Density } \\
\left(@ \quad 15^{\circ} \mathrm{C} \text {, }\right. \\
\left.\mathrm{kg} / \mathrm{m}^{3}\right)\end{array}$ & Fuel Type \\
\hline 1 & Diesel & 47 & 42313 & $2.7\left(38^{0} \mathrm{C}\right)$ & -15.0 & -33.0 & 52 & 870.20 & Conventional \\
\hline 2 & Gasoline & 17 & 42400 & 0.44 & $\mathrm{n} / \mathrm{a}$ & $\mathrm{n} / \mathrm{a}$ & -43 & 682 & Conventional \\
\hline 3 & Palm oil & 42 & $\mathrm{n} / \mathrm{a}$ & $\mathrm{n} / \mathrm{a}$ & $\mathrm{n} / \mathrm{a}$ & $\mathrm{n} / \mathrm{a}$ & $\mathrm{n} / \mathrm{a}$ & 910.1 & Biodiesel \\
\hline 4 & Rubber seed oil & 46 & 9563 & 40.86 & 3.2 & -2.0 & 152 & 880 & Biodiesel \\
\hline 5 & Jatropha oil & 51 & 39700 & $51\left(30^{\circ} \mathrm{C}\right)$ & 16 & $\mathrm{n} / \mathrm{a}$ & 242 & 932 & Biodiesel \\
\hline 6 & Soybean oil & 37.9 & 39623 & $32.6\left(38^{0} \mathrm{C}\right)$ & -3.9 & -12.2 & 254 & 997.5 & Biodiesel \\
\hline 7 & Coconut oil & $\mathrm{n} / \mathrm{a}$ & $\mathrm{n} / \mathrm{a}$ & $\mathrm{n} / \mathrm{a}$ & $\mathrm{n} / \mathrm{a}$ & $\mathrm{n} / \mathrm{a}$ & $\mathrm{n} / \mathrm{a}$ & 924.27 & Bioethanol \\
\hline
\end{tabular}

Source: $[1 ; 27 ; 33 ; 35] ; \mathrm{n} / \mathrm{a}$ (not applicable) 
Synthesized biofuels has no petroleum constituents, but can be blended at varying proportions with conventional fuels to generate various grades like bioethanol and ethanol as $\mathrm{B}_{\mathrm{xx}}$ and $\mathrm{E}_{\mathrm{xx}}$ grades (Figure 3), respectively. Without any special adjustment in the compression ignition (CI) or spark ignition (SI) engines, the mix has been described as quality alternatives by the vehicle and engine manufacturers' up to $20 \%$ at ASTM D675 specifications [34]. Pre-processing of each feedstock differs, but fermentation (carbohydrates into ethanol), distillation (ethanol to aqueous ethanol, $95 \%$ by steam distillation) are same, because of the formation of water-ethanol azeotrope from the fermented mash and dehydrating process (gasoline miscible by-product through residual water removal) to churn out anhydrous ethanol $(>99.5 \%)$.

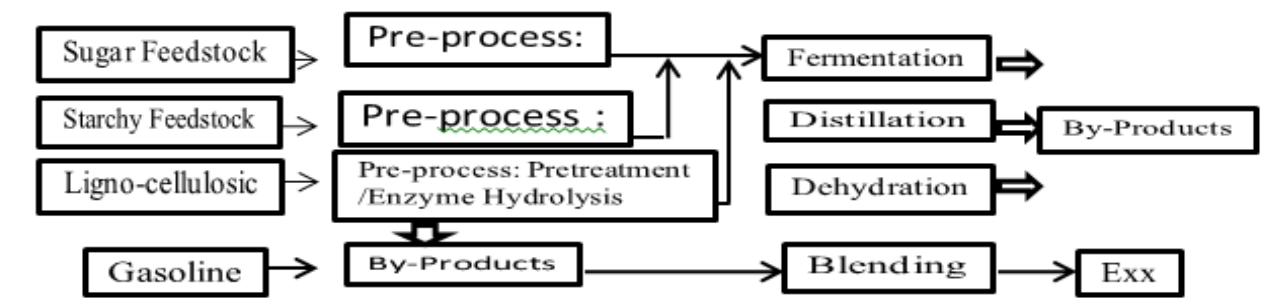

a.

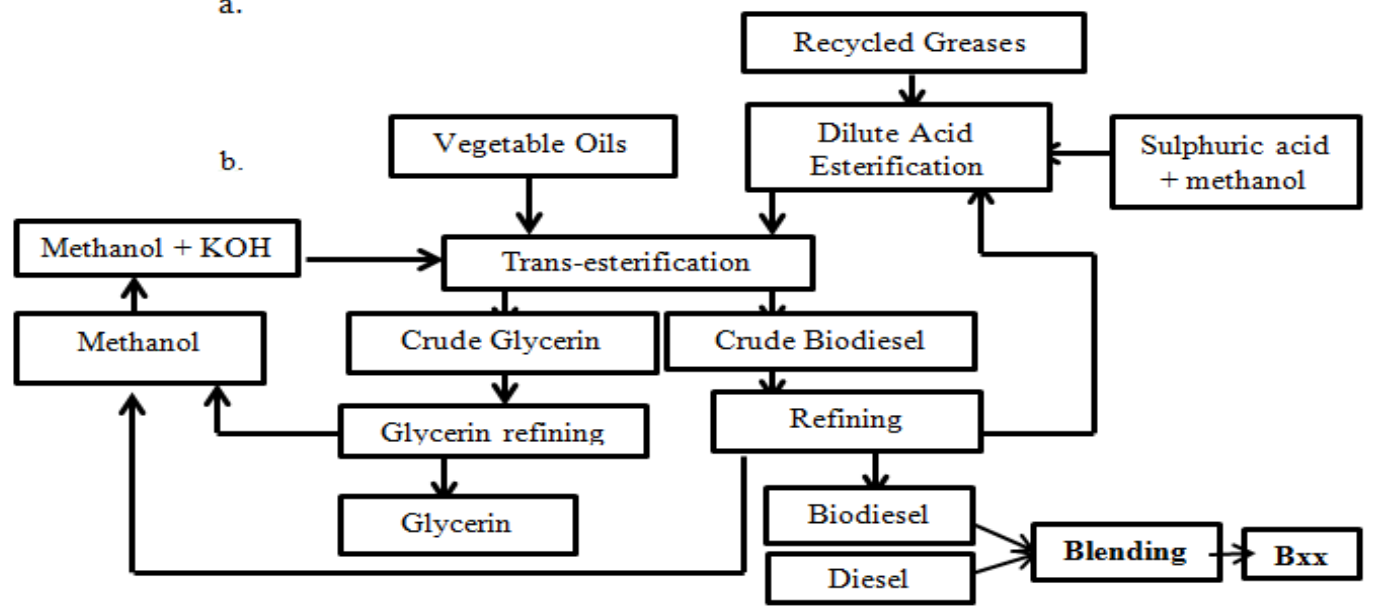

Figure 3: a: Ethanol Production before blending from different feed stocks; b: Flow diagram for biodiesel production Source: $[8,30]$

Chemical synthesis yields better quality than mechanical process, i.e., extraction and yeast-fermentation of sugar-crops (simple sugar) produces a first generation ethanol, of $70 \%$ less energy due to higher octane value when blended with gasoline, whereas, the biodiesel produced by chemical process of trans-esterification of oil using ethanol or methanolgenerates 88 to $95 \%$ of traditional diesel energy content, giving improved lubricity andcetane value, with fuel economy delivery capacity of traditional diesel [8]. The scarcely available advanced technology for the commercialization of the second generation ethanol through lingo-cellulosic biomasses such as waste seed husks and stalks should not limit the production of biofuel from other sources [36], Short and long-term engine testswhich have been carried out by researchers on different plant oils through chemical alterations and blends with diesel fuel to prevent premature engine failure includes Bruwer et al., (1980b),they studied the performance of sunflower seed oil $(100 \%)$, as a replacement for diesel fuel in a farm tractor operation [37]. They reported an $8 \%$ power defect over a thousand $(1,000)$ hours of operation, corrected by using injector pumps and fuel injectors. They reported that there was carbonization after 1,300 hours of operation which was same measure with a $100 \%$ diesel fueled engine, except for the excessive carbon on the injector tip. Oyebanji et al., (2017) examined the bio-oils make up developed by swift thermal cracking of two (2) energy biomass, namely; west africancordia $(\mathrm{Cm})$ and africana birch (Al). They reported that with the use of a gas chromatography-mass spectrometry (GC-MS) analyzer that sawdust from the two biomass produced pyro-fuels usable as fuel and raw material for processing chemicals manufactured after purification [38]. Audu and Aluyor, (2012) conducted a study on the potential development of bioenergy and biofuels technology in Nigeria. They reported the method of biomass based diesel and Fischer-Tropschgasoline (liquids), and power coproduction as a vital stride of boosting the national energy through bio-energy. The automobile sector may profit well from the co-existence of the present delivery arrangement of 
this Fischer-Tropsch liquids on a medium/long term when adopted [39].

\section{Effect of Fuel Compatibility and Viscosity on Engine Performance}

According to Uriartes (2012), the most challenging factor in using biodiesel engine fuel is oxidation instability(moisture content), carbon residue (ash content), flash point (temperatures and volatility), and cetane index (delay interval and combustibility), viscosity (injector lubrication and fuel atomization) and density (weight per unit volume of energy per litre) [30].Chemical composition and storage conditions make biodiesel susceptible to oxidation [40; 41; 42; 43]. Compatibility of biodiesel with automotive materials is equally important $[44 ; 45]$. Report reveals that biodiesel absorb moisture (ASTM E203, 0.050 wt. \%) with time compared to conventional diesel, which will affect combustion [35]. Also, the heating value, viscosity and lubricity of biodiesel feedstock have less energy per unit volume effect of 3-6\% on the engine performance compared to traditional diesel fuel[46]. Typically, fall in fuel economy is $7 \%$ for every $10 \%$ biodiesel blended with a drop-off of $3-$ $5 \%$ of similar ranged peak engine power [47].

Classical research inferences revealed that power reduction and increased fuel consumption is true for biodiesel engine, but magnified, especially with micro-emulsified hybrid fuel based surfactants that has improved diesel- oil-water solubility producing homogeneous mixtures of single phase, e.g. $n$-butanol which is more stable and less viscous [48]. Meanwhile, adequate mixing by dissociation of bulk liquid jets to small droplets for complete combustion in an injection engine reduces emissions and increases engine efficiency after the reduction of the biodiesel surface tension property [49]. Biodiesel atomization due to large sautermean-diameter (SMD) can be enhanced by blending it with ethanol which has lower kinematic viscosity in order to improve its viscosity [50]. According to Engine Manufacturers Association (EMA), a 200-hour engine screening test with fuels likediesel:butanol:soybeanoil:cetane-improver $\quad(33: 33: 33: 1), \quad$ diesel:190 proofethanol:soybean-oil:butanol, (50:5:25:20) and soybeanoil:2-octanol:methanol:cetane-improver, (53:33:13:1) were reported to show performance potential comparable to that of diesel fuel [51]. An actual field test conducted by LAUD Technologies on an old cargo truck using different microemulsified hybrid fuels (MHF) blends ranged MHF5 to MHF30 for several months over a distance of 8,000 kilometers reveal that there was a vanish of the normal black smoke, greater acceleration and pulling power, with 2-5\% enhancement in fuel utilization. Engine was opened before the field test was carried out and after 8,000 kilometers for observation but there was negligible change in the appearance and inside-engine condition [30].

\section{Effect of Fuel on Wear, Corrosion, Clogs and Low} Temperature Emission Effect

Biofuel's lubricity reduces engine wear due to its gel nature at high temperatures which helps to prolong engine lifetime. Short-period engine wear from the utilization of biodiesel had been reported to be lesser compared to petroleum diesel [30]. Therefore, engines are expected to have lesser wear in the longterm run even with the smallest percentage of biodiesel addition to conventional diesel (B1; 1\% biodiesel, 99\% diesel) due to air-quality advantages [52]. On corrosion however, the absorbed water will reduce the combustion heat and lead to corroding of important fuel system components such as fuel and injector pumps, fuel tubes. The ASTM D2709 and ES ISO 12937 standards help to constrain the amount of water to 0.05 vol. $\%$.

On clogging, low temperatures results to wax formation at cloud point (CP) and pour point (PP) levels, i.e., insoluble gums from oxidation of low quality biodiesel can block fuel filter and affect engine durability considering the cloud filter plugging point (CFPP) from ASTM D6371 point of view. If fuel quality is high enough, fuel oxidation and deposits on the engine should normally not be pronounced, according to Adebowale et al., (2012), and Adebowale and Adedire, (2006). They reduced the soapy formation ability of the vetiaperuviana seed oil by a one-step pre-treatment via trans-esterification to give a biodiesel yield of $98.02 \%$, and also reported the modification of the chemical properties of Jatrophacurcas seed oil to give an impact resistance and chemical resistance properties [52; 57], respectively. The quality biodiesel results in much less air pollution (high oxygen constituents), does not contain both aromatic compounds and sulphur, carbon monoxide, soot formation, small particles, and hydrocarbon emissions (by $\geq 50 \%$ ), reducing cancer-risk attribution of diesel-biodiesel blend up to $90 \%$ [30], with reference to ASTM D445 and ES ISO 3104 specifications. Proper tuning of the engine can minimize the nitrogen oxide $\left(\mathrm{NO}_{\mathrm{x}}\right)$ emission associated problem of biodiesel use. Also, peak heat release rate (HRR), maximum pressure gradient (MPG), peak incylinder bulk-gas-averaged temperature, total hydrocarbon (HC) emissions, opaque smoke, and NOx emissions increases with increasing degree of unsaturation [58; 59; 60]. Though, unblended biodiesel operates well at temperatures of about $5^{\circ} \mathrm{C}$, cold flow additives or improvers like OS110050, Bio Flow-870; Bio Flow-875 and diesel fuel antigel are able to improve the operation range within 5 to $8^{\circ} \mathrm{C}$ to temperatures $\leq-20^{\circ} \mathrm{C}$ workable range [61].

\section{Effect of Production Process on Yield}

Towering rate of conversion, low cost, corrosiveness, and temperature requirements has made $\mathrm{NaOH}$ a good choice in the production of biodiesel from vegetable oils [62]. More so, the most used solvent is methanol among other alcohols, and it is as a result of its good polarity, 
recovery, and low cost, although it increases rate of reaction [63; 64]. Free fatty acids (FFAs), contaminants, reactor type, agitation speed, reaction time, temperature, catalyst type and concentration, solvent-to-oil ratio, solvent type are vital choices $[65 ; 66]$ for a good quality oil yield during the biodiesel production. Halim et al. (2009) compared the biodiesel production of cooking waste oil to palm oil [67]. They reported that biodiesel yield from waste cooking oil was lower compared to palm oil as a result of towering water content that led to substrate hydrolysis and subsequently a cut down on yield [68; 69]. Ademiluyi and Mepba examined the ethanol yield and properties of five different cassava flours [70]. They investigated the effect of yeast quantity, cassava flour converted to acid, mineralized media ratio of ethanol yield, and the physical characteristics of ethanol produced from the several cassavas. They noted that the density, distillation range, flash point and viscosityof ethanol produced vary slightly for different investigated cassava types, while the ethanol yield and its electrical conductivity varies significantly. They attributed the yield differences of ethanol to variation of starch content, protein content, and types of cassava dry matter. They concluded that enhanced yield of ethanol from the entire cassava flour is best produced from cassava types having low protein content and fiber as well as high starch content. Consequently, adoption of biofuel may unburden fossil fuel dependence by diversification.

\section{Biofuel from Residual Wastes}

Production of biofuel from wastes (food, municipal, agricultural, etc.) has great potentials. The report by ASABE S593.1 standard describes biomass as consisting of plant or animal based organic materials, including agricultural produce like food and remains of fiber crop, aquatic plants, forest woods, agricultural wastes, bio-based sectors of industrial and municipal wastes, processed products and other non-fossil organic materials[71]. There are three major classes of biomass, namely; primary, secondary and tertiary biomass [71]. The primary biomass types are direct product of photosynthesis from the field or forest, i.e. grains, perennial grasses, wood crops, crop remains and remains from logging and forest operations. The secondary biomass includes remains andfrickle of food, feeds, fibers, fuel-wood and materials from processed plants (i.e. sawdust, black liquor and cheese whey), and manures from concentrated animal feeds. Tertiary biomass sources are post-consumer wastes like fats, greases, oil, construction and demolition wood debris, wastages of wood from urban environments, municipal solid s as well as landfill gases [71]. Wan Omar and Saidina Amin, (2011); Yaakob et al., (2013) reported that the use of biodiesel from renewable resources, such as food wastes (FW) and waste cooking-oil is low in emission, non-toxic, biodegradable, and carbon neutral [72; 73]. Hence, records for better perspective on collection and planning for most renewable residue is necessary to meet biofuel targets. Yaakob et al., 2013, Chen et al., 2009, Mahmood and Hussain, 2010, Papanikolaou et al., 2011, Pleissner et al., 2013 reported that food wastesare converted to fatty acids and biodiesel using trans-esterification of microbial oils produced by various oleaginous microorganisms. Figure 4 highlights the different phases of world food wastages in the food supply chain. The inefficient harvest methods, unsuitable infrastructures, processing and packaging facilities, as well as inefficient marketing information are the challenges associated with biofuel production from wastes. This involves a good plan to collect, recycle, process, and dispose of waste materials in many countries $[73 ; 74 ; 75 ; 76 ; 77]$,i.e., the wastes resource collection extent in Nigeria is highlighted in Table 3.

Table 3: Wastes Resource Collection in Nigeria.

\begin{tabular}{|l|l|l|}
\hline S/N & Biomass Type of Resource & Production \\
\hline $\mathbf{1}$ & Fuel Wood & 0.120 million tonnes/day \\
\hline $\mathbf{2}$ & Animal Wastes & 0.781 million tonnes of wastes/day \\
\hline $\mathbf{3}$ & Energy Crops \&Agric Wastages & 0.256 million tonnes of assorted crops/day \\
\hline
\end{tabular}

Incidentally, Melikoglu et al., (2013) and Katami et al., (2004) reported that the traditional waste management system of landfilling and incineration with and without energy recovery fromfood waste (FW) with other municipal solid waste (MSW) gives carbon dioxide, oxides of nitrogen, sulfur dioxide and traces of toxic pollutants, like dioxins [79; 80]. Meanwhile, Adhikari et al., (2009) noted that $8 \%$ of world's anthropogenic methane emissions are from landfills [81]. Melikoglu et al., 2013 recounted that the processes require environmental consideration and prioritization [79]. The prevention of the carbon, nitrogen, phosphorus and mineral wastes generated during food supply chain (FSC) needs modern strategies based on nature-friendly chemical technologies deployed to accomplishing economical and environmentally sustainable development in the value-added products from the conversion of FW. According to Lin et al., (2013), the practicability and economic benefit of FW conversion to chemicals and biofuels have been demonstrated, using technologies like microwave-assisted extraction of valued 
components, biological (i.e., fermentation) and chemoenzymatic methods in the synthesis of bio-derived products [82]. Agriculture related waste dominates most in the food supply chain and should be a primary target for the production of biofuel (Figure 4) as Tjell (2005) reported that the major challenge is that considerable percentages of leftover food perishes and are not always edible, generating ever increasing mountains of waste that need to be considered for biofuel [83].

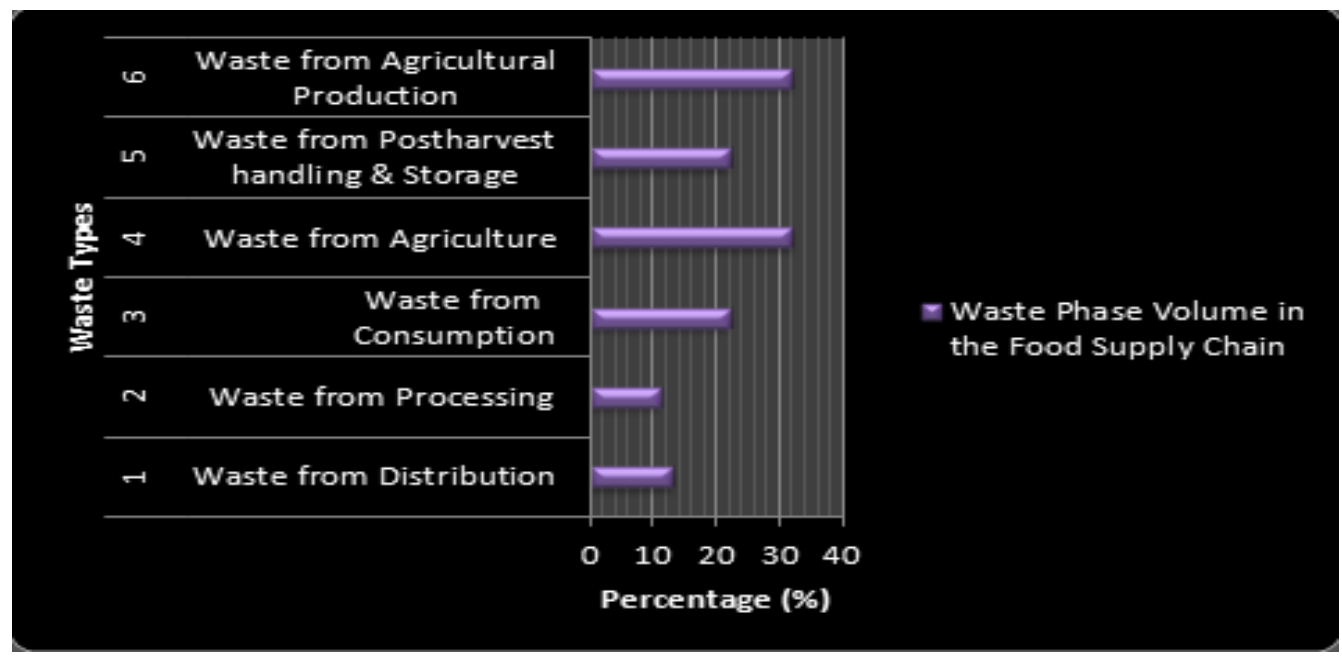

Figure 4: Phases of world relative food wastage in the food supply chain. [84]

\section{INDIRECT ENVIRONMENTAL IMPACTS OF BIOFUELS}

The standard life-cycle assessment (LCA) of biofuels in literatures establishes a total reduction in green-house gas(GHG) emissions as a result of underlying perception of system limits, associated-product distribution, and means of energy utilised in agricultural input production and feedstock to biofuels conversion for specific feedstock, example is the co-generation of usable heat, electricity and liquid fuel in certain biofuel production technologies. A typical case is the ethanol, the process energy from sugarcane wastage (bagasse) and electricity cogeneration [85] all from sugarcane, estimate revealing the reduction of GHG emissions of $90 \%$ by ethanol from sugarcane as compared to an equivalent amount of gasoline [36]. Savings will be more pronounced (i.e. 100\%) in cases where the cogeneration of electricity is made to substitute coal-fired electricity from the grid [86]. However, a broad-scale adoption of biofuel over fossil fuels may lead to release of GHG associated with forest or land clearing to measure up with increased crop demand to supply feedstock for biofuels and food simultaneously. Use of nitrogen fertilizer for feedstock production as an example will have its effect on climate even as feedstock are indirectly intended to replace fossil fuel [87]. This means biofuel-GHG savings reduces with indirect land use change of existing cropland for cultivation of feedstock (Table 4).

Table 4: GHG Balance of Selected Feedstock and Land Use Change Emission, 2005.

\begin{tabular}{|l|l|l|l|l|l|}
\hline S.N & Feedstock & Previous Land Use & LUC: None & LUC: Direct & LUC: Indirect \\
\hline 1. & Biodiesel & & & & \\
\hline a & Waste Oil & n/a & -90 & n/a & n/a \\
\hline b & Rapeseed & Crop Land & -58 & -58 & 5 to 69 \\
\hline c & Rapeseed & Pasture & -58 & -25 & 39 to 102 \\
\hline $\mathbf{2 .}$ & Ethanol & & & & \\
\hline d & Maize & Crop Land & -55 & -55 & -22 to 11 \\
\hline e & Maize & Pasture & -55 & -37 & -5 to 28 \\
\hline f & Wheat & Crop Land & -49 & -49 & 6 to 63 \\
\hline g & Wheat & Pasture & -49 & -20 & 36 to 92 \\
\hline
\end{tabular}

Source: [88]Fritsche\&Wiegmann (2008) in [87] Fischer et al. (2009); n/a - not applicable

Where LUC= land use change;

LUC: Direct $=$ emissions from land conversion to cultivate biofuel feedstock;
LUC: indirect mean emissions arising from the conversion of land;

n/a: means not applicable. 
Most of the particulate matters (PMs) and combustive fuel emissions which threatens public health can be attributed to the transport sector inurban areas [89]. So, it can be deduced that in biofuel production, persistent burning of cleared vegetation leads to smog, which affects human morbidity and mortality negatively [90]. However, for the purpose of better atmospheric condition, other synthesized fuel types should be compared with biodiesel fuel as in the Table 5 below:

Table 5: Average Exhaust Pollutants Relative to Low Sulfur Diesel

\begin{tabular}{|l|l|l|l|l|}
\hline $\mathbf{S} / \mathbf{N}$ & Fuel Type & NOx $(\boldsymbol{\%})$ & PM $(\boldsymbol{\%})$ & VOC(\%) \\
\hline $\mathbf{1}$ & B100 & 10 & -37 & -76 \\
\hline $\mathbf{2}$ & B20 & 3 & -10 & -24 \\
\hline $\mathbf{3}$ & B5.75 & 1 & -2 & -4 \\
\hline $\mathbf{4}$ & Unleaded Petrol & -88 & -95 & -9 \\
\hline $\mathbf{5}$ & LPG & -96 & -95 & 36 \\
\hline $\mathbf{6}$ & CNG & -89 & -94 & -73 \\
\hline
\end{tabular}

Source: [91; 92 in 93].Note: Medium-sized passenger car based emissions.

\section{LAND USE IMPACT AND TARGET}

Conversion of non-agricultural land and diverse agroforestry systems into growing biofuel crops promotes direct land use change. Conversion may be designated at a larger level to biofuel companies, with support from governmental policies, atmedium scale to entrepreneurs with rights to forest land use, or at much smaller scale by individual farmers [94]. An indirect land use change is when a piece of land that is currently in use for the production of food/feed crops (e.g., corn) or croplands (e.g., corn fields) is diverted into production of biofuels (e.g., corn-based bioethanol), causing farmers to use non-agricultural land to replace the displaced land for crop production. The global approximate of land surface for crop production, grassland, forest and urban settlements are 1.5, 3.5, 3.9, and 0.2 billion hectares, out of the 13.4 billion hectares of earth's land surface. Deserts, mountains and other unsuitable land for productive use fill the remaining 4.2 billion hectares [86; 95], and
Nigeria has $81.8 \%$ agricultural land from its total land area of 91,077,000 ha [96]. The biofuel target of any country will determine the required area of land to cultivate. In order to accommodate the production of biofuel, it is appropriate to estimate beyond the traditional demands of agriculture and forestry and accommodate wastages or residues. This estimate should include population growth per capita consumption, biofuel target, existing hectare of land per quantity of biofuel production, needed hectare of land to augment existing cultivation, etc. Several studies have proposed different methodologies to estimate land requirements for particular biofuel targets [97; 98; 99; 100; $93 ; 101 ; 102 ; 103 ; 104]$. The Table 6 shows Nigeria ethanol projection on the medium term where the nation despite its abundant available resources as shown in figure 2, does not have a record of any biofuel export but import. The nation is however, yet to capture its overall production, domestic use, import and exports (if applicable) on biofuel.

Table 6: Ethanol Projection (Nigeria)

\begin{tabular}{|l|l|l|l|l|}
\hline S/N & Index & $\begin{array}{l}\mathbf{2 0 1 5 - 1 7} \\
\text { (Million Litres) }\end{array}$ & $\begin{array}{l}\mathbf{2 0 2 7} \\
(\text { Million Litres) }\end{array}$ & $\begin{array}{l}\text { Growth Rate } \\
(\%)\end{array}$ \\
\hline $\mathbf{1}$ & Production & 17 & 57 & 8.77 \\
\hline $\mathbf{2}$ & Imports & 160 & 154 & 0.0 \\
\hline $\mathbf{3}$ & Domestic Use & 177 & 211 & 1.74 \\
\hline $\mathbf{4}$ & Export & n/a & n/a & n/a \\
\hline
\end{tabular}

Source: [105]; n/a - not applicable

Meanwhile, the target in table 1 could be realized without import of biofuel if planned well such that there is balanced distribution in cultivated land areas throughout the geopolitical zones (or states) to achieve its targeted projections in terms of projected gasoline and diesel volumes.

\section{BIOFUEL ESTIMATIONS}

The production of biofuel to meet targets in this study includes crops feedstock and wastes. It is expected that use of feedstock andproper collection of waste is a potential combination that will not cause food scarcity through biofuel competition.

\section{Biofuel Estimation from Waste}

Wastes are most times scattered and needs to be collected together. Waste production capacity by Nigeria companies from cassava flour and starch production is 5tonne/day, from average generation of $495 \mathrm{~kg}$ wastes/tonne[106]. The nitrogen source in different additives has its effect on the volume of 
ethanol produced (Figure 5). Nigeria generates $49.51 \%$ wastes from its annual 57 MT (million tonnes) of cassava tubers. The biofuel and animal feed manure percentages from the wastes are 40 and $60 \%$ respectively. The cassava waste conversion rate to ethanol is 150 litres per tonne[107]. The E5; E10 (95\% gasoline and 5\% ethanol; $90 \%$ gasoline and $10 \%$ ethanol) requirement to meet up daily local refinery production of 8 million litre (ML) of gasoline/premium motor spirit (PMS) from cassava wastes in Nigeria is estimated as $3.3 \%(146,000,000 \quad$ Litre/yr $)$ and $6.9 \% \quad(292,000,000$ Litres/yr). Ethanol extraction through yeast nitrogen source produces most volumes (litre/tonne) and the coefficient of determination shows that cassava flour/starch peel though produces more volume than cassava flour/starch pulp but lacks consistency when ammonia extract and urea nitrogen source are used in ethanol production process (Figure 5).

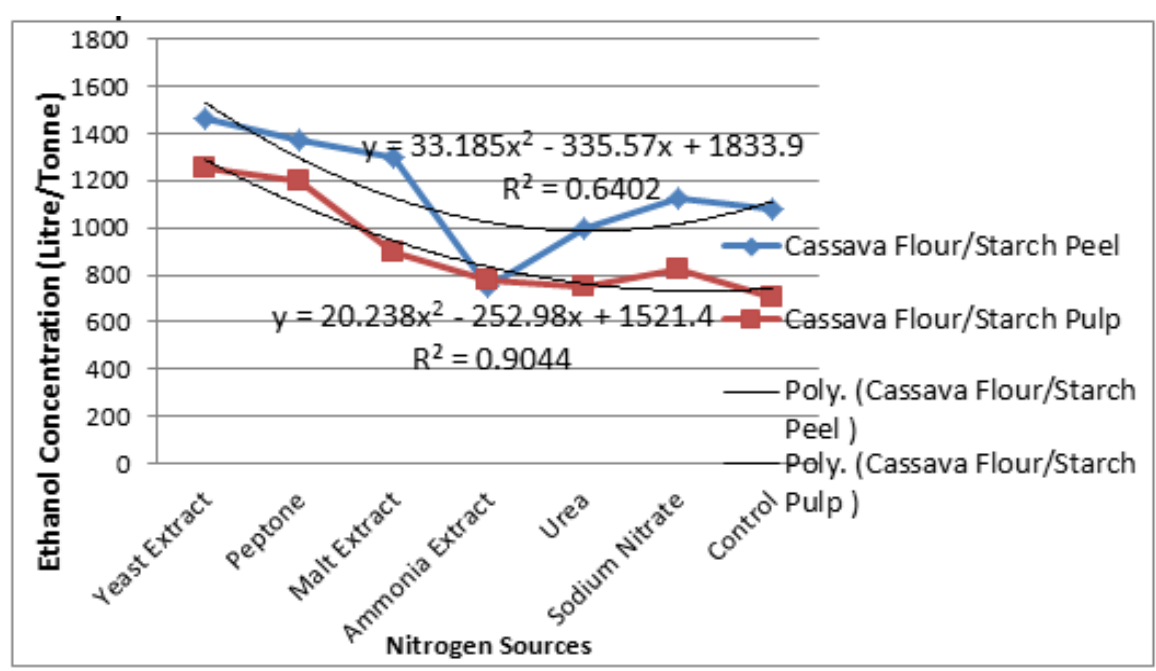

Figure 5: Nitrogen source-effect on ethanol production from cassava pulp and peel [107]

\section{Biofuel Estimations from Crop Feedstock}

It is assumed that plant spacing for global agronomic best practice is same.

\section{Selected feedstock:}

Ethanol - Cassava, Sorghum, Maize;

Biodiesel - Palm oil, Jatropha and Rubber seed.

Targeted gasoline and diesel volumes, respectively: $\psi_{\mathrm{G}}$ and $\psi_{\mathrm{D}}$ (litres); Expected Yield and biofuel targets (EBT): Ethanol and Biodiesel: $\alpha_{\mathrm{E}}$ and $\alpha_{\mathrm{B}}$ (litres)

Existing Yield (EY) for ethanol and biodiesel:

$\varepsilon \psi_{\mathrm{E}}$ and $\varepsilon \psi_{\mathrm{B}}$
Total Oil Yield (TOY) for ethanol and biodiesel: $\varepsilon \psi_{E}+\alpha_{E}$; $\varepsilon \psi_{\mathrm{B}}+\alpha_{\mathrm{B}}$

EBT for Short and Medium terms (based on Table 1):

Ethanol on short and medium terms: $\alpha_{\mathrm{E}}=0.325 \psi_{\mathrm{G}}$ and $0.575 \psi_{\mathrm{D}}$ Biodiesel on short and medium terms: $\alpha_{\mathrm{B}}=$ $0.026 \psi_{\mathrm{G}}$ and $0.18 \psi_{\mathrm{D}}$

The oil yield (litre/hectare) of common biofuel feedstock for targeted biofuel volume is given in the Table 7 .

Table 7: Oil yield of common/projected feedstock in Nigeria, [108; $109 ; 110 ; 111 ; 112 ; 113]$.

\begin{tabular}{|l|l|l|}
\hline S/N & Feedstock & Oil (Litre/hectare) \\
\hline 1 & Cassava & 6000 \\
\hline 2 & Sorghum & 2800 \\
\hline 3 & Maize & 2050 \\
\hline 4 & Palm oil & 5950 \\
\hline 5 & Jatropha C. & 1892 \\
\hline 6 & $\begin{array}{l}\text { Rubber seed } \\
\text { (i) } \mathbf{R}_{\mathbf{L}} \\
\text { (ii) } \mathbf{R}_{\mathbf{U}}\end{array}$ & $\begin{array}{l}80 \\
120\end{array}$ \\
\hline
\end{tabular}

Where, $\mathrm{R}_{\mathrm{L}}$ - Rubber yield lower limit; Rubber; $\mathrm{R}_{\mathrm{U}}-$ Rubber yield upper limit. 
Hence, projected number of hectare per yield (litre) of Ethanol as percentage (\%) of targeted gasoline, Table 1 for Short and Medium terms are given as;

Cassava (Ethanol, $\alpha_{\mathrm{E}, \mathrm{C} 1,2)}=0.00017 *\left(0.325 \psi_{\mathrm{G}}\right.$ and $\left.0.575 \psi_{\mathrm{G}}\right) \mathrm{ha} / \mathrm{lit}$

Sorghum $\left(\right.$ Ethanol, $\left.\alpha_{\mathrm{E}, \mathrm{S} 1,2}\right)=0.00036 *\left(0.325 \psi_{\mathrm{G}}\right.$ and $\left.0.575 \psi_{\mathrm{G}}\right)$ ha/lit

Maize $\left(\right.$ Ethanol, $\left.\alpha_{\mathrm{E}, \mathrm{M} 1,2}\right)=0.00049 *\left(0.325 \psi_{\mathrm{G}}\right.$ and $\left.0.575 \psi_{\mathrm{G}}\right) \mathrm{ha} / \mathrm{lit}$

Projected numbers of hectare per litre of biodiesel as \% of targeted Diesel, Table 1) for Short and Medium terms aregiven as;

Palm oil (biodiesel, $\left.\alpha_{\mathrm{B}, \mathrm{P} 1,2}\right)=0.00017 *\left(0.026 \psi_{\mathrm{D}}\right.$ and $\left.0.18 \psi_{\mathrm{D}}\right)$ ha/lit

Jatropha(biodiesel, $\left.\alpha_{\mathrm{B}, \mathrm{J} 1,2)}\right)=0.00053 *\left(0.026 \psi_{\mathrm{D}}\right.$ and $\left.0.18 \psi_{\mathrm{D}}\right)$ ha/lit

Rubber seed (biodiesel, $\alpha_{\mathrm{B}}, \mathrm{RL}$ ) at 80 lit/ha $=0.0125 *$ $\left(0.026 \psi_{\mathrm{D}}\right.$ and $\left.0.18 \psi_{\mathrm{D}}\right)$ ha/lit;

Rubber seed (biodiesel, $\left.\alpha_{\mathrm{B}}, \mathrm{RU}\right)$ at $120 \mathrm{lit} / \mathrm{ha}=0.0083 *$ $\left(0.026 \psi_{\mathrm{D}}\right.$ and $\left.0.18 \psi_{\mathrm{D}}\right)$ ha/lit

* Note that RL and RU are Rubber lower yield and upper bound levels, ha $=$ hectares, lit $=$ litres .

Nigeria's production of E10 gasohol (10\% ethanol and $90 \%$ gasoline) from cassava will generate 59,485,947 tonnes and 285,714 jobs based on one direct job per hectare and one off-farm in 2017 [114], its daily production capacity of 8 million litre of PMS from its domestic refineries in the interim, will require 800,000 litre of ethanol $(292,000,000$ litre/annum) which can be supplied by cultivating 16,133 and 28,543 hectares of cassava plantation annually on short and medium terms.

\section{Energy Estimation of Fuel Cell (DEFC) from Ethanol.}

Pursuant of energy for direct ethanol fuel cell (DEFC), assuming uniform yield (Table 7) and equivalent daily production capacity of $(8,000,000$ litres) PMS to ethanol production requirement 800,000 litre of E10.

Specific energy of DEFC from Ethanol $=8.0 \mathrm{KWh} / \mathrm{Kg}$,[115] Estimating an equivalent 8million litre (E10) target for DEFC energy generation, specific energy of DEFC for 292,000,000 litre/annum

$$
=8 \times 292,000,000=2.34 \mathrm{GWh} / \mathrm{Kg} .
$$

Specific energy estimate from 800,000 litre ethanol is 2.34 $\mathrm{GWh} / \mathrm{Kg} /$ annum of energy.

Future automated development in the transport industry favors adapting electric vehicles (EVs) and hybrid electric vehicles (HEVs) with renewable fuel (biofuel for fuel cell).This will help to cut down dependence on battery charging time. These are the potentials of biofuel-based vehicles in the interim and long-term.

\section{CONCLUSION}

The potential biofuel resource, contemporary status, sources, impact, required waste and cultivation as well as notable challenges to meet biofuel target has been presented using
Nigeria as a case study, in line with the European Commission proposal of twelve percent (12\%) biofuels market share for year 2020 [116]. Other conclusion includes:

1. Biodiesel feedstock (jatropha, rubber seed, palm, soybean, etc.) and bioethanol feedstock (cassava, maize, sugarcane, sorghum, etc.) and wastes from pulps and peels of cassava are the major biofuel resource from Nigeria. Automotive fuel feedstock and wastes to fuel conversion could be used to check hike in food prices before deep exploration of other biofuels and bioenergy carriers like biogas, bio-char and FischerTropsch fuels.

2. The annual E10 gasohol target from Nigeria agricultural and total land mass from cassava is estimated at 0.022 and $0.018 \%$ on short term; and 0.038 and $0.031 \%$ on medium term. Biofuel targets can be met by augmenting feedstock with biofuel processed from wastes as the E5/E10 blend needs 3.3 and $6.9 \%$ of cassava wastes from its local production to ensure there is no food-fuel competition. This will equally guarantee a viable enterprise that can provide domestic jobs through small scale bio-ethanol mini-refineries, encourage agricultural mechanization, improved varieties of crops, proper collection of wastes and sustainable nutrient management.

3. Greenhouse gas from fossil fuels will be checked with the use of well refined biofuel or biofuel blends in automotive applications. More so, charging time in Battery Electric Vehicle can be checked with renewable source (ethanol) alternative using direct ethanol fuel cell.

Finally, effect of biofuel price, climate change and currency variability will be cushioned through planning, income generation, jobs, thereby, limiting food crisis and sustain energy security. This study should help to minimize carbon footprint, cut down on fossil fuel and insight on how to realize the energy targets at short and long term.

\section{Recommendations}

Feedstock for biofuel should be mapped out separately from food-stock to lessen threat on food security through feedstock/food-stock plan and sensitization on the benefit of agro-based industries for biofuel production. Training of workers in the agri-based field, for example, on methods to overcome periodic unavailability and storage systems is essential for requisite knowledge and smooth running of the production system.

\section{Other Limitation}

Sustenance of the biofuel project needs:

1. Overcoming structural land ownership and support on large scale cultivation of energy crops and collection of wastes from industries which may need some form of approval from the government to disallow 
communal encroachment and interference which can disrupt the availability of raw material.

2. Adequate awareness, monitoring and assessments of financial and fiscal incentives to encourage the supply and demand of feedstock for the production of biofuel especially in rural communities may through provision of long term loans and incentives.

\section{REFERENCES}

1. Gaurav, D., Jain, S., and Sharma, M.P. (2013). Diesel engine performance and emission analysis using biodiesel from various oil sources. Review. Journal of Material and Environment Science 4, (4): $434-$ 447.

2. Rajput, R.K., Testing and performance of IC engines. (A Text Book of Automobile Engineering, Google Books.Books.google.co.in.,Laxmi Publications, 2005), 1-1004, ISBN 817008637X, 9788170086376.

3. OPEC Oil Reserve Data (2020). Annual Statistical Bulletin 2014: OORD 2012. Accessed April, 2020, http://www.opec.org/opecweb/en/datagraphs/330.htm

4. Enibe, S.O., and Odukwu, A.O. (1990). Pattern of energy consumption in Nigeria," Energy Conversion and Management 30(2): 69 - 73. doi.org/10.1016/ 0196-8904(90)90015-Q.

5. Lashof, D.A. and Ahuja, D.R. (1990). Research needs for improving biofuel burning cook-stove technologies. Natural Resource Forum 12 (2): 25 134. doi:10.1111/j.1477-8947.1990.tb00378.x

6. Intergovernmental Panel on Climate Change, (2020).Mitigation of Climate Change, Contribution of Working Group III to the Fourth Assessment Report, Draft, IPCC 2007.Accessed May, 2020, http://www.mnp.nl/ipcc/pages_media/AR4chapters.html.

7. Sarin, A., Biodiesel: production and properties, (Royal Society of Chemistry (RSC) Publishing, 2012), doi.org/10.1039/9781849734721.

8. Albino, D.K., Bertrand, K.Z., and Bar-Yam, Y. (2012). Food for fuel: the price of ethanol. Accessed May 2020, http://necsi.edu/research/social/foodprices/foodforfuel.

9. Petroleum B, (2013).BP biofuels fact sheet 2013.AcessedApril, 2020,

http://www.bp.com/content/dam/bpalternate.../en/.../ bp-biofuels-factsheet.pdf.

10. Govinda, R.T., and Ashish, S., (2010).Policy Research Working Paper on Biofuels - Markets, Targets and Impacts.Presentation at the World Bank Development Research Group Environment and Energy Team, Lisbon, Portugal, pp.1-49. July, 2010. doi: 10.1596/1813-9450-5364.

11. Demirbas, A. (2008).Comparison of transesterification methods for production of biodiesel from vegetable oils and fats. Energy Conversion
Management $49 \quad$ (1) (2008): 125-30. doi.org/10.1016/j.enconman.2007.05.002.

12. National Ethanol Vehicle CoalitionE85 (2008). Refueling location search. Number of stations in leading states complemented with search on. Accessed February, 2021. www.ethanolproducers.com.

13. Michelle Kautz (2008). E85 Stations exceeds 1800. National Ethanol Vehicle Coalition. Accessed February, 2021.

14. Energy Information Administration (2014). Annual U.S. biodiesel production and consumption, selected states (2001-2018).

www.eia.gov/todayinenergy/detail.php?.Acessed May, 2021.

15. Farinelli, B., Carter, C.A., Lin, C.C., and summer, D.A. (2009). Important demand for Brazilian ethanol: a cross-country analysis. Journal of Cleaner Production, 17(1): 9-17. doi:10.1016/j.jclepro.2009.05.008

16. Ohimain, E.I. (2013). Environmental impacts of smallholder ethanol production from cassava feedstock for the replacement of kerosene household cooking fuel in Nigeria. Energy Sources A, 35 (16): 1560-1565. doi: 10.1080/15567036.2019.529565.

17. Tuck, C.O., Perez, E., Horvath, I.T., Sheldon, R.A., and Poliakoff, M. (2012). Valorization of biomass: deriving more value from waste. Science, 337 (6095): 695-699. doi: 10.1126/science. 1218930

18. Demirbas, A. (2008). New liquid biofuels from vegetable oils via catalytic pyrolysis. Energy Education Science and Technology, 21 (1-2): 1-59.

19. www.eia.gov (2014). U.S. Product supplied for crude oil for petroleum products. eia.gov. Acessed May, 2021.

20. Leong, B.S., Rus, M., Zafiah, A., and Hasan, S. (2013). Continuous biodiesel production using ultrasonic clamp on tubular reactor. Proceedings of the International Conference on Mechanical Engineering Research (ICMER), Kuantan, Pahang, Malaysia, pp. 1-10; July, 2013.

21. Energy Commission of Nigeria(2008). Communiqué of National workshop on sustainable Jatropha for energy development, ECN, 2008. 6-7th May, Mambayya house, Kano. Accessed April, 2020, www.energy.gov.ng.

22. Halim, S.F.A., Kamaruddin, A.H., and Fernando, W.J.N. (2009). Continuous biosynthesis of biodiesel from waste cooking palm oil in a packed bed reactor: optimization using Response Surface Methodology (RSM) and mass transfer studies. Bioresource Technology, 100,(2): 710-716. doi.org/10.1016/j.biortech.2008.07.031.

23. Galadima, A., Garba, Z.N., Ibrahim, B.M., Almustapha, M.N., Leke, L., and Adam, I.K. (2011). Biofuels Production in Nigeria. The Policy and 
Public Opinions Journal of Sustainable Development, 4(4): 22-31. doi:10.5539/jsd.v4n4p 22.

24. Ohimain, E.I. (2010). Emerging bio-ethanol projects in Nigeria: Their opportunities and challenges. Energy Policy, 38 (11): 7161-7168, doi: 10.1016/j.enpol.2010.07.038.

25. Goering, C.E., and Fry, B. (1984). Engine durability screening test of a diesel/ soy oil/alcohol microemulsion fuel.Journal of American Oil Chemists Society, 61: 1638-1643. doi.org/10.1007/BF02541647.

26. Ziejewski, M., Kaufman, K.R., Schwab, A.W., and Pryde, E.H. (1984). Diesel engine evaluation of a nonionicsun flower oil-aqueous ethanol microemulsion. Journal of American Oil Chemist's Society, 61: 1620-1626. doi.org/10. 1007/BF02541646.

27. Zanuttini, M.S., Pisarello, M.L., and Querini, C.A. (2014). ButiaYatay coconut oil: Process development for biodiesel production and kinetics of esterification with ethanol. Energy Conversion and Management, 85: 407-16.

doi.org/10.1016/j.enconman.2014.05.080.

28. Tan, K.T., Lee, K.T., and Mohamed, A.R. (2011). Potential of waste palm cooking oil for catalyst free biodiesel production. Energy, 36 (4): 2085-2088. doi:10.1016/j.energy.2010.05.003.

29. Carraretto, C., Macor, A., Mirandola, S., Stoppato, A., and Tonon, S. (2004). Biodiesel as alternative fuel: experimental analysis and energetic evaluations. Energy, 29 (12): 2195-2211. doi:10.1016/j.energy.2004.03.042

30. Uriarte, F.A. (2012). Biofuels from Plant Oils: A Book for Practitioners and Professionals Involved in Biofuels, to Promote a Better and More Accurate Understanding of the Nature, Production, and Use of Biofuels from Plant Oils," (ASEAN Foundation, Indonesia), 1-166, ISBN 9791968411, 9789791968416

31. Schwab, A.W., Dykstra, G.J., Selke, E., Sorenson, S.C., and Pryde, E.H. (1988). Diesel fuel from thermal decomposition of soybean. Journal of American Oil Chemists' Society, 65: 1781-1786. doi:10.1007/BF02542382

32. Jain, S., and Sharma, M.P. (2010). Review of different test methods for the evaluation of stability of biodiesel. Renewable and Sustainable Energy Review, 14(7): 1937-47. doi.org/10.1016/j.rser.2010.04.011

33. Abila, N. (2011). Promoting Biofuels Adoption in Nigeria: A Review of Socio-economic Drivers and Incentives. Paper presented at World Renewable Energy Congress,LinkÖping, Sweden 359-364; May, 2011. doi: 10.3384/ecp1105 7359.
34. Clean Cities Coalition Network (2020).Energy Efficiency and Renewable Energy.Accessed February, 2020, www.cleancities.energy.gov./accomplishments.

35. Ahmad, J., Yusup, S., AwaisBokhari, A., and Kamil, R. (2014). Study of fuel properties of rubber seed oil based biodiesel. Energy Conversion and Management, 78: 266-275. doi: 10.1016/j.enconman.2013.10.056.

36. Organisation for Economic Cooperation and Development (2008). Biofuels Support Policies: An Economic Assessment, Paris, (OECD Publishing, 2008), 146. doi.org/10.1787/9789264050112-en.

37. Bruwer, J.J., Boschoff, B., Van, D., Hugo, F.J.C., Fuls, J., Hawkins, C., Van der Walt, A.N., Engelbrecht, A., du Plessis, L.M. (1980). Sunflower oil as extender for Diesel Fuel in Agricultural Tractors. Paper presented at South African Institute for Agricultural Engineers Symposium. June, 1980, pp. 1-7. South Africa.

38. Oyebanji, J.A., Okekunle, P.O., Lasode, O.A., and Oyedepo, S.O. (2017). Chemical composition of biooils produced by fast pyrolysis of two energy biomass.Biofuels,pp.1-10.doi: 10.1080/17597269.2017.1284473.

39. Audu, T.O.K., and Aluyor, E.O. (2012). Potential of bioenergy and biofuels technology development in Nigeria. Petroleum Technological Development Journal, 1: 1-7.

40. Sarin, R., Sharma, M., Sinharay, S., and Malhotra, R.K. (2007). Jatropha-palm biodiesel blends: an optimum mix for Asia. Fuel, 86 (10-11):1365-71. doi.org/10.1016/j.fuel.2006.11.040.

41. Knothe, G. (2007). Some aspects of biodiesel oxidative stability. Fuel Processing Technology 88 (7): 669-677. doi.org/10.1016/j.fuproc.2007.01.005.

42. Dunn, R.O. (2002). Effect of oxidation under accelerated conditions on fuel properties of methyl soyate. Journal of American Oil Chemist's Society 79: 915-20. doi:10.1007/S11746-002-0579-2.

43. Knothe, G. (2008). Designer Biodiesel: Optimizing Fatty Ester Composition to Improve Fuel Properties. Energy and Fuels, 22(2): 1358-1364. doi: 10.1021/ef700639e.

44. Thomas, E.W., Fuller, R.E., and Terauchi, K. (2007). Fluoroelastomer compatibility with biodiesel fuels.SAE Technical Paper 2007-01-40061. doi.org/10.4271/2007-01-4061.

45. Mitra, S., Ghanbari-Siahkali, A., Kingshott, P., Rehmeier, H.K., Abildgaard, H., and Almdal, K. (2006). Chemical degradation of crosslinked ethylene-propylene-diene rubber in an acidic environment, part I: effect on accelerated sulphur crosslinks. Polymer Degradation and Stability, 91(1): 69-80.

doi.org/10.1016/ j.polymdegradstab.2005.04.032. 
46. Xue, J., Grift, T.E., and Hansen, A.C. (2011).Effect of biodiesel on engine performances and emissions. Renewable and Sustainable Energy Reviews (15): 1098-1116. doi: 10.1016/j.rser.2010.11.016

47. PennState Extension (2016). Using-biodiesel-fuel-inyour-engine. Pennsylvania state University. Accessed June, 2016, https://extension.psu.edu.

48. Googin, J.M., Compere, A.L., and Griffith, W.L. (1983). Technical considerations in choosing alcohol fuels for less-developed countries.Energy Research, 3: 173 lu2013186.

49. Shu, Q., Wang, J., Peng, B., Wang, D., and Wang, G. (2008). Predicting surface tension of biodiesel by a mixture topological index method at $313 \mathrm{~K}$. Fuel, 87: 3586-3590.doi: 10.1016/j.fuel.2008.07.007

50. Deng, P.P., Rhodes, J.I., and Lammers P.J. (2010). Conversion of waste cooking oil to biodiesel using ferric sulfate and supercritical methanol processes," Fuel, 89 no. 2 (2010): 360-364. doi: 10.1016/j.fuel.2009.05.024

51. Bagby, M.O., "Vegetable Oils: Precombustion Characteristics and Performance as Diesel Fuels," American Chemical Society, Division of Petroleum Chemistry 31, no.1 (1986): 191. doi.org/10.4271/2007-01-4061.

52. Adebowale, K.O., Adewuyi, A., and Ajulo, K.D. (2012). Examination of fuel properties of the bimethyl esters of Thevetiaperuviana seed oil. International Journal of Green Energy, 9 (3): 297307.

doi.org/10.1080/ 15435075.2011.621480

53. Adebowale, K.O., and Adedire, C.O. (2006). Chemical composition and insecticidal properties of the underutilized Jatrophacurcas seed oil. African Journal of Biotechnology 5, (10): 901-906. doi.org/10.5897/AJB05.424.

54. Benjumea, P., Agudelo, J.R., and Agudelo, A.F. (2011). Effect of the degree of unsaturation of biodiesel fuels on engine performance, combustion characteristics and emissions Energy. Fuels, 25 (1): 77-85. doi.org/ 10.1021/ef101096x

55. Lapuerta, M., Armas, O., Rodríguez, J. (2008). Effect of biodiesel fuels on diesel engine emissions. Progress in Energy and Combustion Science 34 (2): 198-223. doi.org/10.1016/j.pecs.2007.07.001.

56. Nabi, Md.NS.,Akhter, Md.S., Shahadat, M.M.Z. (2006). Improvement of engine emissions with conventional diesel fuel and diesel-biodiesel blends. Bioresource Technology, 97(3): 372-378. doi: 10.1016/j.biortech.2005.01.013.

57. Chiu, C.W., Schumacher, L.G., and Suppes, G.J. (2004). Impact of cold flow improvers on soybean biodiesel blend. Biomass Bioenergy, 27 (5): 485-91. doi: 10.1016/j.biombioe.2004.04.006.

58. Ejikeme, P.M., Anyaogu, I.D., Ejikeme, C.L., Nwafor, N.P., Egbuonu, C.A.C.,Ukogu, K., and
Ibemesi, J.A., (2010). Catalysis in biodiesel production bytransesterification processes. An insight. E-Journal of Chemistry, 7 (4): 1120-1132. doi:10.1155/2010/689051

59. Le, T.T., Okitsu, K., Luu, V.B., and Maeda, Y. (2012). Catalytic technologies for biodiesel fuel production and utilization of glycerol: A review. Catalysts, 2 (4): 191-222. doi: 10.3390/cata2010191.

60. Romano, S.D., and Sorichetti, P.A. (2011). Introduction to biodiesel production, in: Dielectric spectroscopy in biodiesel production and characterization," Green Energy and Technology, Springer: pp. 7-27.doi:10.1007/978-1-84996-5194_2.

61. Shahzad, K., Nizami, A.S., Sagir, M., Rehan, M., Maier, S., Khan, M.Z., Ouda, M., Ismail, L.M.I., and BaFail, A.O. (2017). Biodiesel production potential from fat fraction of municipal waste in Makkah.PLoS ONE, 12(2): e0171297: 1-14. doi:10.1371/journal.pone.0171297

62. Voca, N., Krieka, T., Janu, V., Ana, J., and Darko, M. (2008). Fuel properties of biodiesel produced from different raw materials in Croatia," Journal of Mechanical Engineering, 54 (3): 232-244.

63. Azocar, L., Ciudad, G., Heipieper, H.J., and Navia, R. (2010). Biotechnological processes for biodiesel production using alternative oils. Application of Microbiology and Biotechnology, 88: 621-636. doi: 10.1007/s00253-010-2804-z

64. Fjerbaek, L., Christensen, K.V., and Norddahl, B. (2009). A review of the current state of biodiesel production using enzymatic transesterification. Biotechnology and Bioengineering, 102 (5): 1298 1315. doi:10.1002/bit.22256.

65. Ademiluyi, F.T., and Mepba, H.D. (2013). Yield and Properties of Ethanol Biofuel Produced from Different Whole Cassava Flours.ISRN Biotechnology, 916481: 1-6. doi.org/10.5402/2013/916481

66. American Society of Agricultural and Biological Engineers (2011). Terminology and definition for biomass production, harvesting and collection, storage, processing, conversion and utilization: (ANSI/ASABE S593.1. 821-824). Acessed January, 2020.

https://standards.globalspec.com/std/9981020/asabes593.

67. Wan Omar, W.N.N., and Saidina Amin, N.A. (2011). Optimization of heterogeneous biodiesel production from waste cooking palm oil via response surface methodology. Biomass and Bioenergy, 35 (3): 1329 1338. doi.org/10.1016/j.biombioe.2010.12.049.

68. Yaakob, Z., Mohammad, M., Alherbawi, M., Alam, Z., and Sopian, K. (2013). Overview of the production of biodiesel from waste cooking oil. 
Renewable and Sustainable Energy Reviews, 18: 184-193. doi:10.1016/j.rser.2012.10.016

69. Chen, Y., Xiao, B., Chang, J., Fu, Y., Lv, P., and Wang, X. (2009). Synthesis of biodiesel from waste cooking oil using immobilized lipase in fixed bed reactor," Energy Conversion and Management, 50 (3): 668-673, doi.org/10.1016/j.enconman.2008.10.011.

70. Mahmood, T., and Hussain, S.T. (2010). Nanobiotechnology for the production of biofuels from spent tea. African Journal of Biotechnology, 9(6) (2010): 858-868. doi:10.5897/AJB09.1555.

71. Papanikolaou, S., Dimou, A., Fakas, S., Diamantopoulou, P., Philippoussis, A., GaliotouPanayotou, M., and Aggelis, G. (2011). Biotechnological conversion of waste cooking olive oil into lipid-rich biomass using Aspergillus and Penicillium strains. Journal of Applied Microbiology, 110(5): 1138-1150, doi: 10.1111/j.1365-2672.2011.04961.x.

72. Pleissner, D., Lam, W.C., Sun, Z., and Lin, C.S.K. (2013). Food waste as nutrient source in heterotrophic microalgae cultivation. Bioresource Technology, 137: 139-146. doi.org/10.1016/j.biortech.2013.03.088.

73. Sambo, A.S. (2009). The challenges of sustainable energy development in Nigeria. Paper presented at the Nigerian Society of Engineers Forum, Shehu Musa Yar'Adua Centre, Abuja, Nigeria; April, 2009.

74. Melikoglu, M., Lin, C.S.K., and Webb, C. (2013). Analysing global food waste problem: pinpointing the facts and estimating the energy content. Central European Journal of Engineering, 3 (2): 157-164, doi.org/10.2478/s13531-012-0058-5.

75. Katami, T., Yasuhara, A., and Shibamoto, T. (2004). Formation of dioxins from incineration of foods found in domestic garbage. Environmental Science and Technology, 38 (4): 1062-1065, doi:10.1021/es030606y.

76. Adhikari, B.K., Barrington, S., and Martinez, J. (2009). Urban food waste generation: challenges and opportunities. International Journal of Environment and Waste Management, 3 (1/2): 4-21, doi:10.1504/IJEWM.2009.024696

77. Lin, C.S.K, Pfaltzgraff, L.A., Herrero-Davila, L., Mubofu, E.B., Abderrahim, S., Clark, J.H., Koutinas, A.A., Kopsahelis, N., Stamatelatou, K., Dickson, F., Thankappan, S., Mohamed, Z., Brocklesby, R., and Luque, R. (2013). Food waste as a valuable resource for the production of chemicals, materials and fuels: Current situation and global perspective. Energy \& Environmental Science, 6 (2): 426-464, doi:10.1039/C2EE23440H

78. Tjell, J.C. (2005). Editorial: Is the 'waste hierarchy' sustainable?," Waste Management and Research, 23 (3): 173-174, doi:10.1177/0734242X0502300301.
79. Food and Agriculture Organization of the United Nations (2014b). Food Wastage Footprint: Impacts on Natural Resources. Accessed June 2020 http://www.fao.org/docrep/018/i3347e/i3347e.pdf.

80. Macedo, I.C., Seabra, J.E.A., and Silva, J.E.A.R. (2008). Greenhouse gases emissions in the production and use of ethanol from sugarcane in Brazil: The 2005/2006 averages and a prediction for 2020. Biomass and Bioenergy, 32(7): 582-595, doi:10.1016/j.biombioe.2007.12.006

81. Doornbosch, R., and Steenblik, R. (2007). Biofuels: Is the cure worse than the disease?," Paper presented at the 20th meeting of the OECD Round Table on Sustainable Development, Paris, France, September, 2007.

82. Fischer, G., Eva, H., Sylvia, P.,Mahendra, S., and Harrij, V. (2009). Biofuels and Food Security. Paper prepared by the International Institute for Applied Systems Analysis (IIASA) for OPEC Fund for International Development (OFID), pp. 1 - 223, May, 2009.

83. Fritsche, U.R., Hennenberg, K.J., and Wiegmann, K. (2008). Bioenergy and Biodiversity: Potential for Sustainable Use of Degraded Lands. Briefing Paper for the Information Event at CBD-COP9 2008, Darmstadt, May, 2008.

84. Krzyzanowski, M., Kunna-Dibbert, B., and Schneider, J. (2005). Health effects of transportrelated air pollution. World Health Organization Geneva, Europe, pp. 190; 2005.ISBN 92-890-1375-3.

85. Schwela, D., Haq, G., Huizenga, C., Han, W., Fabian, H., and Ajero, M. (2006). Urban Air Pollution in Asian Cities: Status, Challenges and Management, 1st ed. (Earthscan Publications, 2006), 276 , doi.org/10.4324/9781849773676.

86. Beer, T., Grant, T., Williams, D., and Watson, H. (2002). Fuel cycle greenhouse gas emissions from alternative fuels in Australian heavy vehicles," Atmospheric Environment, 36 (4): 753-763. doi: 10.1016/S1352-2310(01)00514-3

87. Morris, R.E., Pollack, A.K., Mansell, G.E., Lindhjem, C., Jia, Y., Wilson, G. (2003). Impact of biodiesel fuels on air quality and human health," Summary report of National Renewable Energy Laboratory. ENVIRON International Corporation Novato 2003, California. Accessed May, 2020 http://www.nrel.gov/vehicles andfuels/npbf/pdfs/33793.

88. Russi, D. (2008). An integrated assessment of a large-scale biodiesel production in Italy: Killing several birds with one stone? Energy Policy, 36 (3): 1169-1180. doi:1016/j.enpol.2007.11.016

89. Koh, L.P., and Ghazoul, J. (2008). Biofuels, biodiversity, and people: understanding the conflicts 
and finding opportunities. Biological Conservation 14 (10): 2450-2460.

doi.org/10.1016/j.biocon.2008.08.005.

90. FAO. (2003). World Agriculture: Towards 2015/2030.An FAO perspective. Edited by J. Bruinsma. Earthscan Publications Ltd., 2003, ISBN:92 51048355.

91. Simonyan, K.J., and Fasina, O. (2013). Biomass resources and bioenergy potentials in Nigeria. African Journal of Agricultural Research, 8(40):4975-4989.doi: 10.5897/ajar2013.6726.

92. Organisation for Economic Cooperation and Development (2006). Agricultural Market Impact of Future Growth in the Production of Biofuels: (OECD, 2006). Acessed February, 2020. https://www.oecd-

ilibrary.org/economics/agricultural-market-impactsof-future-growth-in-the-production-of-

biofuels_oecd_papers-v6-art1en.

93. European Commission (2006). Communication from the Commission to the Council and the European Parliament: Renewable Energy Road Map, Renewable energies in the 21 st century: building a more sustainable future.COM 848 final. Brussels. Belgium. 2006.

94. Gurgel, A., Reilly, J.M., and Paltsev, S. (2007). Potential Land Use Implications of a Global Biofuels Industry. Journal of Agricultural and Food Industrial Organization, 5 (2): Article 9.

95. Nowicki $\mathrm{P}$, Meijl $\mathrm{H}$, van Knierim A, Banse $\mathrm{M}$, Helming J, Margraf O, Matzdorf B, Mnatsakanian R, Reutter M, Terluin I, Overmars K, Verhoog D, Weeger C, Westhoek H. (2007). Scenar 2020 Scenario study on agriculture and the rural world. Contract No. 30 - CE - 0040087/00-08. European Commission, Directorate-General Agriculture and Rural Development, Brussels. 2007.

96. Food and Agricultural Policy Research Institute (2008).US and world agricultural outlook. (FAPRI Staff Report 08-FSR 1 ISSN 1534-4533). Iowa State University and University of Missouri-Columbia, Ames, IO. 2008.

97. Food and Agriculture Organisation (2008).Climate Change, Biofuels and Land, Info sheet for the Highlevel Conference on World Food Security: the Challenges of Climate Change and Bioenergy. Rome, June, 2008.

98. Ravindranath, N.H., Manuvie, R., Fargione, J., Canadell, J.G., Berndes, G., Woods, J., Watson, H., and Sathaye, J. (2008). Greenhouse gas implications of land use and land conversion to biofuel crops.Pp. 111- 125, in R.W. Howarth and S. Bringezu, editors. Biofuels: Environmental Consequences and Interactions with Changing Land Use. Proceedings of the Scientific Committee on Problems of the Environment (SCOPE) International Biofuels Project
Rapid Assessment, Gummersbach Germany.Cornell University, Ithaca NY, USA. September, 2008.

99. Ozdemir, E.D., Marlies, H., and Ludger, E. (2009).Land substitution effects of biofuel side products and implications on the land area requirement for EU 2020 biofuel targets. Energy Policy, 37: 2986-2996. doi.org/10.1016/j.enpol. 2009.03.051.

100.OECD/FAO. (2018). OECD-FAO Agricultural Outlook: OECD Agriculture statistics (database). OECD, 2018. Accessed March, 2020.

https://www.oecd-ilibrary.org /agriculture-andfood/data/oecd-agriculture-statistics_agr-dataen.doi:dx.doi.org /10.1787/agr-outl-data-en. 22.

101.Ogbonna, J.C., Ndubuisi, I.A., Murata, Y., and Omae, H. (2018).Production of Ethanol from Cassava Processing Wastes in Nigeria. Paper presented at the $8^{\text {th }}$ session of the International Renewable Energy Agency (IRENA) Assembly. Abu Dhabi, UAE. January, 2018. Accessed December 2019.

https://www.irena.org//media/Files/IRENA/Agency/ Publication/2018/Dec/IRENA_Sustainable_rural_bio energy_SSA_2018.pdf.

102.Wang, W. (2002).Cassava production for industrial utilization in China - Present and future perspectives: Cassava Research and Development in Asia: Exploring New Opportunities for an Ancient Crop. Paper presented at the 7 th regional cassava workshop; Bangkok, Thailand, Oct. 28 - Nov. 1 2002, 1-673.

103. Bin, A., and Ghazali, Y. (2015).Bio-based products from rubber, jatropha and sunflower oil. ([S.1.]: [S.n.], 2015: 197, ISBN 978-90-367-7644-8.

104. Jansson, C., Westerbergh, A., Zhang, J., Hu, X., and Sun, C. (2009).Cassava, a potential biofuel crop in china. Applied Energy, 86 (1): 95-95. doi.org/10.1016/j.apenergy.2009.05.011

105. Calais, P., Clark, A.R. (2007).Vegetable Oil as a Diesel Replacement Fuel. Environmental Science, Murdoch University and Western Australian Renewable Fuels Association Incorporated, Perth, Australia.Accessed January 2020, <http://www.shortcircuit.com.au/warfa/paper/paper.

106. Leibig, R. (2008).Comparison of energy-saving and cost-efficient technology for ethanol production. Accessed January 2020.

www.biofuelsukraine.com/.2008

/Biofuels_Ukraine_Leibig_Eng.pdf.

107. Mobius, L.L.C. (2007).What is biodiesel: the long explanation.Acessed January, 2020. www.mobiusbiofuels.com/biodiesel.htm./2007.

108.Food and Agriculture Organisation (2009).FAOStat database on world crop production.(FAO, 2009). Accessed February 2020, http://faostat.fao.org/site /567/ default.aspx\#ancor. 
109. Food and Agriculture Organization of the United Nations.FAOSTAT Statiscal database, statiscal Division, Rome (2019).Accessed January 2020, http://www.fao.org/statistics/en/.

110. Penyarat, S. and Bordindech, J. (2017). Study on the Performance of the Micro Direct Ethanol Fuel Cell (Micro-DEFC) for Applying with the Portable Electronic Devices. International Conference on Alternative Energy in Developing Countries and Emerging Economies 2017 AEDCEE, May 2017, Bangkok, Thailand. Energy Procedia, 138: 187-192.

111. Korbitz, W. (1999).Biodiesel production in europe and north america, an encouraging prospect. Renewable energy, 1699: 1078-1083. doi.org/10.1016/S0960-1481 (98)00406-6. 